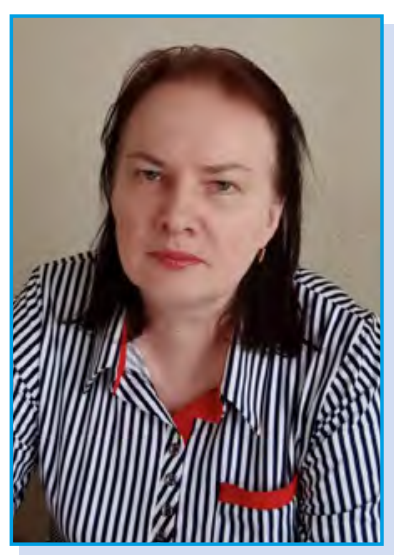

Світлана Трубачева - кандидат педагогічних наук, старший науковий співробітник, завідувач відділу інновацій та стратегій розвитку освіти Інституту педагогіки НАПН України, м. Київ, Україна.

Коло наукових інтересів: теорія навчання, освітні технології, формування ключових компетентностей учнів, проєктування інноваційного освітнього середовища закладу загальної середньої освіти.

trubachevas@gmail.com

https://orcid.org/0000-0002-1400-9773

кандидат педагогічних наук, старший науковий співробітник, старший науковий співробітник відділу інновацій та стратегій розвитку освіти Інституту педагогіки НАПН України, м. Київ, Україна.

Коло наукових інтересів: прогнозування та проектування інноваційного освітнього середовища закладу загальної середньої освіти.

ivmbroker@gmail.com

https://orcid.org/0000-0001-6083-2499

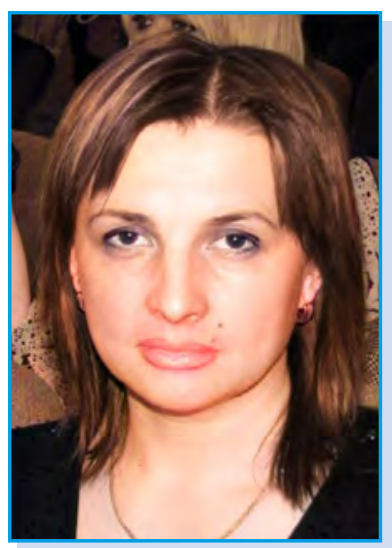

УДК 373.3/.5.018.54

https://doi.org/10.32405/2411-1317-2021-4-142-148

\title{
ТРАДИЦІї ТА ІННОВАЦІЇ У ПРОЄКТУВАННІ ОСВІТНЬОГО СЕРЕДОВИЩА СУЧАСНОÏ ГІМНАЗІЇ
}

Стаття присвячена аналізу, систематизації та узагальненню основних методологічних та дидактичних положень, які покладені в основу сучасного етапу проєктування освітнього середовища гімназії як закладу загальної середньої освіти II ступеня. Процес проєктування моделі освітнього середовища гімназії передбачає такі аспекти: концептуальний, організаційноуправлінський, змістовий, технологічний. Розкривається сутність як актуальних традиційних, так й інноваційних принципів проєктування кожного з висвітлених складників освітнього середовища. Аналізуються шляхи їх реалізації в сучасному освітньому процесі гімназії.

Ключові слова: освітнє середовище; гімназія; принципи проєктування освітнього середовища.

Постановка проблеми. Модернізація навчальних програм і підручників, варіативність змісту освіти зумовлюють необхідність удосконалення сучасного технічного, інформаційного і методичного забезпечення освітнього середовища, конструювання і визначення нових цілей і завдань освіти в основній школі, яка в умовах Нової української школи асоційована з гімназійною освітою. Системному рішенню цих завдань має посприяти створення освітнього середо- 
вища, яке буде спроєктовано на основі актуальних традиційних та пріоритетних інноваційних дидактичних принципів.

У педагогіці принципами вважають загальні положення, які визначають стрижневі напрями організаційної діяльності педагога в навчальному процесі та освітній системі. Часто науковці розглядають дві групи педагогічних принципів: методологічні і дидактичні. До першої групи відносять такі принципи: культурологічний, антропологічний, моністичний, синергетичний, герменевтичний, валеологічний (Ярошинська, 2016). До дидактичних принципів автор відносить загальні принципи, принципи, що стосуються цілей і змісту навчання, принципи, що охоплюють дидактичний процес і адекватну йому педагогічну систему з ії елементами.

Методологічними орієнтирами проєктування освітнього середовища гімназії є особистісна спрямованість, принципи гуманізації та гуманітаризації, розгляд змісту освіти як однієї із умов для становлення особистості, успішного входження її у життя суспільства. Провідними стають не засвоєння формальних знань і навичок, а гуманність стосунків, свобода самовиявлення, культивація індивідуальності, творча самореалізація особистості (Trubacheva, Onyschuk, 2019).

Освітнє середовище містить цільові установки, вимоги до освіти, соціокультурні ресурси, авторські моделі педагогічної діяльності викладачів і потенціал педагогічного колективу, нормативно-правові документи, що регулюють відносини у сфері освіти, матеріально-предметну і рекреаційну базу навчального закладу. Усі ці чинники й умови виникають як під впливом соціально-економічних процесів, так і цілеспрямовано створюються в системі освітнього закладу. Їх аналіз, узагальнення та систематизація є актуальними в процесі проєктування освітнього середовища гімназії (Доброханська, 2013).

Аналіз останніх досліджень і публікацій. Освітнє середовище закладу освіти розглядається як штучно побудована система, в якій здійснюється формування та розвиток особистості у процесі спеціально організованого навчання з метою досягнення нею освітніх результатів. Його розглядають як особливий технологічний засіб, формуванням якого можна управляти. Освітнє середовище було предметом дослідження зарубіжних і вітчизняних учених і практиків. Під освітнім середовищем розуміють сукупність умов, які сприяють досягненню певного педагогічного результату. Теоретико-методологічні засади навчання молоді в інтегрованому освітньому середовищі досліджувала І.Б. Іванова, Л. Л. Ордіна висвітлила методологічні засади формування культуротворчого середовища закладу вищої освіти. Н.Б. Гонтаровська, О.О. Нечаєва та О.О. Ярошинська дослідилии принципи розроблення проєкту освітнього середовища. Усе це доводить важливість правильно обраних засадничих положень для реалізації завдання проєктування освітнього середовища.

Проте питання проєктування освітнього середовища сучасної гімназії в умовах Нової української школи досліджені недостаньо і на особливу увагу заслуговують сьогодні питання методологічних засад та принципів його проєктування.

Метою статті $\epsilon$ аналіз, систематизація та узагальнення основних методологічних та дидактичних положень, які покладені в основу сучасного етапу проєктування освітнього середовища гімназії як закладу загальної середньої освіти II ступеня.

Основні результати дослідження. Проєктування освітнього середовища може здійснюватися з метою його створення, модернізації або підтримки в мінливих умовах процесу реформування системи освіти. Проєкт освітнього середовища передбачає його структурносистемне представлення, яке відображає взаємозв'язок основних компонентів, зумовлений визначеною метою, цілями і завданнями. Процес проєктування моделі освітнього середовища гімназії передбачає такі аспекти: концептуальний (визначення методологічних засад процесу проєктування освітнього середовища, основних функцій і структурних характеристик, критеріїв його ефективності); організаційно-управлінський (розроблення нормативно-установчих документів, підготовка педагогів до застосування освітніх технологій в умовах компетентнісного підходу, ініціація та створення проєктних груп); змістовий (трансформація змістових і процесуальних характеристик запропонованої моделі освітнього середовища); техно- 
логічний (впровадження проєктних і дослідницьких педагогічсних технологій). (Trubacheva, Onyschuk, 2019).

Реалізації концептуального аспекту значною мірою сприяє визначення пріоритетних принципів процесу проєктування освітнього середовища.

До традиційних, універсальних принципів навчання, які значно впливають на процес проєктування освітнього середовища, доцільно віднести такі принципи: науковості (орієнтація на передові наукові досягнення у відповідній галузі); системності (облік системних характеристик досліджуваного явища, їх цілісності і структурних зв’язків); варіативності (альтернативний характер наукового пошуку, виділення й оцінка всіх можливих варіантів рішення, використання в кожному випадку конкретних особливостей об’єкта); динамічності (об’єкт дослідження містить внутрішні сили для саморозвитку, існує тільки в динаміці); прогностичності (вироблення ймовірного судження про стан об’єкта в майбутньому, дослідження перспектив розвитку) (Ярошинська, 2016).

Серед інших відомих принципів пріоритетності сьогодні набуває принцип детермінізму. Це пов'язано з орієнтацією особистості в сучасному соціумі на самостійність, відповідальність, визначення відповідності обраній професії, соціальній ролі.

До специфічних положень, які $є$ важливими у реалізації принципу детермінізму, можна віднести: специфіку навчального закладу, що полягає в прагненні зайняти визначену позицію на ринку освітніх послуг, досягнення заданого рівня конкурентоспроможності, підвищення якості освітніх послуг, розширення асортименту спеціальностей, освоєння ніші на ринку освітніх послуг та поліпшення привабливості образу навчального закладу.

Розвиток суб’єктів освітнього середовища, розглядається через протиріччя, які вирішуються суб'єктами: нові соціально-економічні умови, потреби ринку праці ставлять майбутнього фахівця перед проблемою вибору, коригування своєї траєкторії навчання, зміни професійних орієнтацій, розстановки пріоритетів в особистісному розвитку (Гонтаровська, 2005).

Однією із значущих культурологічних ідей освіти сьогодні $є$ її співбуттєвість, що забезпечує унікальність особистісного зростання кожної людини. Індивід існує й розвивається в суспільстві і через суспільство. Наявність і сам характер цих зв'язків (фізичних, фізіологічних, психологічних, соціальних та ін.), динаміка їх перетворення в систему предметних відносин утворює справжню ситуацію розвитку, шукану єдність вихідних передумов розвитку. Тому наступним актуальним принципом можна вважати принцип співбуттєвості суб'єктів освітнього середовища.

Реалізація цього принципу передбачає рівноправну участь суб’єктів у процесі формування освітнього середовища. Навчання вибудовується в режимі діалогу й рефлексії, не тільки на основі власне когнітивних аспектів освіти або засвоєння знання, а й на основі взаємозв'язку когнітивних, комунікативних та особистісно-смислових аспектів освітнього процесу.

Показовими положеннями, які сприяють реалізації принципу співбуттєвості, є дві групи принципів: 1) базові, такі, що охоплюють принципи розуміння, соціального захисту, співпраці, педагогічної підтримки і допомоги, емпатії; 2) прикладні, власне педагогічні, зокрема, принципи дискурсу, толерантності, гри, діалогу.

У зв’язку з цим педагогічну взаємодію можна розглядати як аналог руху в освітньому просторі, напрям якого визначається необхідністю вирішення людиною особистісних запитів та вимог суспільства. Реалізація цього принципу забезпечить ефективність реалізації діалогічної взаємодії суб’єкта з освітнім середовищем, пережитого як співбуття, що створює необхідні передумови для вільного і відповідального вибору. (Гончар, 2012)

До вже більш традиційних положень, що впливають на процес проєктування освітнього середовища, але і сьогодні актуальних, відносимо такі принципи: діяльнісний - маємо на увазі спеціальну організацію діяльності суб'єктів педагогічного процесу із чіткого прогнозування освітнього середовища, його планування, розробки технології його проєктування, відстеженням результату, його оцінкою, самоконтролем у процесі роботи, рефлексуванням отриманих результатів та у підсумку побудови проєкту середовища. 
Культурологічний принцип допомагає визначити джерела й фактори розвитку особистості носія культури, який є презентантом частини культури, проєктує свій розвиток на основі осягнення культури, але й єії творцем як системи цінностей. У зв’язку з цим одним з основних структурних елементів освітнього середовища, які реалізують означені принципи, є зміст освіти, що реалізується через загальноосвітні предмети, курси за вибором, факультативи, гуртки. Він має базуватися на фундаментальному ядрі змісту освіти: системі знань про світ, його природну, соціальну, технологічну та інші складові; інтегрованих знаннях цілісної картини світу, узагальнених та систематизованих професійно орієнтованих знаннях, метазнаннях і універсальних способах навчальної діяльності - усе це забезпечує умови для формування ключових компетентностей та інших метаособливостей особистості (позицій, поглядів, світогляду, системи цінностей, когнітивних схем, досвіду, установок, готовності до вибору майбутнього профілю навчання).

Зміст освіти має бути спрямований на формування в учнів досвіду здійснення пізнавальної, репродуктивної, творчої діяльності й емоційно-ціннісного ставлення до дійсності, що реалізується шляхом застосування відповідних способів діяльності стосовно реальної досліджуваної дійсності: природи, культури, техніки, соціальних комунікацій та інших реальних об'єктів освітніх галузей. Організована щодо цих об’єктів відповідна освітня діяльність учнів має вести до формування у них систематизованих метапредметних (ключових) компетентностей (Трубачева, 2019).

Інтеграційні тенденції в проєктуванні змістового складника освітнього середовища в основному зумовлені дидактичними особливостями реалізації компетентнісного підходу. Компетентнісний підхід у навчанні певним чином спрямований на розуміння та оволодіння учнями універсальними способами діяльності, що забезпечують здобуття, перетворення і використання знань; володіння навичками аналізу та оцінки інформації з позицій ії̈ властивостей, практичної, особистої і суспільної значущості, уміння застосовувати їх у своїй діяльності. В основному він спрямований на формування універсальних знань, які допомагають учню самостійно, творчо й критично мислити, формувати здатність до саморозвитку і самореалізації. Окрім того він сприяє кращому усвідомленню і осмисленню учнями результатів пізнавальної діяльності, на основі яких формується цілісна картина світу.

Сьогодні, як відомо, українські школи можуть розробляти свою освітню програму для 5-9 класів на основі типової освітньої програми, що нещодавно затверджена Міністерством освіти. Державна служба якості освіти підготувала рекомендації для директорів шкіл, як правильно розробити власну освітню програму школи та якою повинна бути структура документа.

Власна освітня програма дає змогу школі реалізувати свою унікальність та автономію. Освітнє середовище буде характеризуватися спільно виробленими цінностями колективу закладу, власним баченням навчального плану та розподілу навчальних годин. Водночас вона розробляється відповідно до державних стандартів загальної середньої освіти та орієнтована на потреби та інтереси учнів цього закладу освіти та його спроможність реалізувати цю програму.

Унікальність освітнього середовища буде характеризуватись кількістю та якістю розроблення однієї наскрізної для усіх рівнів освіти програми або ж різних для кожного рівня. Водночас на кожному рівні та навіть для кожного класу вона може мати власну специфіку. Освітня програма містить перелік модельних навчальних програм, які використовуються закладом освіти, або навчальних програм, розроблених у закладі освіти та затверджених педагогічною радою, а також навчальних програм, затверджених Міністерством освіти і науки.

Освітня програма так чи інакше має враховувати структуру типової освітньої програми, розробляючи власну програму на основі Державного стандарту, може змінювати цю структуру. Актуальними і на сьогодні у процесі розроблення освітньої програми залишаються принципи поглибленого вивчення навчальних предметів, варіативності та диференціації навчання, які й раніше застосовувались гімназіями для формування варіативного компоненту змісту освіти в основній школі.

Проєктування технологічного складника сьогодні зумовлюється активним зростанням актуальності процесу цифровізації в освіті. Метою перетворення освітнього процесу є застосування 
можливостей цифрових технологій з максимальною ефективністю. Метою розвитку технологій у сфері освіти $є$ повна їх адаптація і максимально зручне вбудовування у процес навчання для максимально комфортного вирішення поставлених педагогічних завдань.

Трансформаційні процеси у зазначених групах принципів проєктування освітнього середовища значною мірою сьогодні пов'язані із розвитком дистанційного та змішаного навчання. Сучасна дистанційна освіта здійснюється переважно у віртуальному освітньому просторі, який передбачає проєктування освітнього середовища з урахуванням найновітніших комп’ютерних технологій. Це такі, зокрема, знаряддя, як блоги та мікроблоги, соціальні мережі й системи соціальних презентацій, вікі-проєкти, мультимедійні системи обміну, системи спільних редакторських офісів тощо. Під ці технологічні можливості розробляються, відповідно, нові освітні методичні підходи, що базуються на таких психологічно орієнтованих принципах побудови: надлишковість, доступність спостереженню, доступність когнітивному досвіду суб'єкта, насиченість навчального середовища, його пластичність, позасуб’єктна просторова локалізація та автономність існування, синхронізованість середовища, векторність, цілісність, мотивогенність, імерсивність, інтерактивність тощо (Трубачева, Замаскіна, 2020).

Характерними рисами дистанційного навчання, які вигідно відрізняють її від інших форм освіти, є: гнучкість - навчання відбувається у зручний для здобувача освіти час та зручному місці; модульність - 3 набору незалежних курсів-модулів формується навчальна програма, що відповідає індивідуальним чи груповим потребам; охоплення великої аудиторії - одночасне звернення до багатьох джерел навчальної інформації великої кількості учнів та їх спілкування за допомогою телекомунікаційного зв'язку між собою та з викладачами; економічність - ефективне використання навчальних площ та технічних засобів, концентроване й уніфіковане представлення інформації, використання і розвиток комп'ютерного моделювання; технологічність - використання в освітньому процесі нових досягнень інформаційних технологій, які сприяють входженню людини у світовий інформаційний простір; соціальна рівність - рівні можливості здобуття освіти незалежно від місця проживання, стану здоров'я й соціального статусу; інтернаціональність - можливість здобути освіту в навчальних закладах іноземних держав та надавати освітні послуги іноземним громадянам і співвітчизникам, що проживають за кордоном; нова роль викладача - викладач стає наставником-консультантом, котрий повинен координувати пізнавальний процес, постійно удосконалювати ті курси, які він викладає, підвищувати творчу активність і кваліфікацію відповідно до нововведень та інновацій; позитивний вплив на слухача; якість для підготовки дидактичних засобів залучається найкращий професорсько-викладацький склад і використовуються найсучасніші навчально-методичні матеріали. Технологія дистанційного навчання значною мірою вносить урізноманітнення в освітнє середовище, підвищує рівень його доступності і безбар’єрності зокрема (Іванова, 2007).

Формування суб'єктності, становлення та розвиток соціальної активності учасників проєктно-педагогічного процесу є одним із критеріїв його успішності. Адже, ставши суб'єктом, особистість виробляє індивідуальний спосіб організації діяльності, що відповідає її особливостям, можливостям та потребам. Суб’єкти освітнього середовища виконують інтегруючу, централізуючу, координуючу функції життєдіяльності середовища, кожен з яких упорядковує цілісно всю систему своїх індивідуальних, психофізіологічних, психічних і особистісних можливостей, особливостей з умовами та вимогами діяльності. Загальною підставою проєктованого освітнього середовища можуть і повинні стати рівневі характеристики сутності та орієнтації на розвиток суб'єктності всіх учасників. Адже можливість стати суб'єктом освітньої та професійної діяльності відбувається в процесі інтеріоризації зовнішніх регуляторів у внутрішні, а ефективність і результативність освітнього процесу залежать від адекватності зовнішніх регуляторів до внутрішніх позицій суб’єктності як вчителя, так і учня.

\section{Висновки та перспективи подальших досліджень.}

Сьогодні, основою освітнього середовища гімназії стає своя освітня програма для 5-9 класів, яку, як відомо, українські школи можуть розробляти на основі типової освітньої програми. 
Це є особливо важливим для демонстрації специфіки навчального закладу, прагнення зайняти визначену позицію на ринку освітніх послуг, досягнення заданого рівня конкурентоспроможності, підвищення якості освітніх послуг, розширення асортименту спеціальностей, освоєння ніші на ринку освітніх послуг та поліпшення привабливості образу навчального закладу. Системному рішенню цих завдань має посприяти створення освітнього середовища, спроєктованого на основі актуальних традиційних та пріоритетних інноваційних дидактичних принципів. Проєкт освітнього середовища передбачає його структурно-системне представлення, яке відображає взаємозв'язок основних компонентів, зумовлений метою, цілями і завданнями. Проєктування моделі освітнього середовища гімназії передбачає такі аспекти: концептуальний, організаційно-управлінський, змістовий, технологічний, проєктування яких базується на проаналізованих та систематизованих у статті методологічних та дидактичних положеннях. Сформованість суб'єктності, становлення та розвиток соціальної активності учасників проєктно-педагогічного процесу, його якість і доступність є одними з основних критеріїв успішності та інноваційності.

Трансформаційні та інноваційні процеси, які відбуваються в освіті сьогодні, перетворюють проєктування освітнього середовища в сучасній гімназії на актуальну проблему. Вона ще більшою мірою актуалізується через стрімкий розвиток освіти, ії цифровізацію, становлення принципів цифрової дидактики.

\section{Використані джерела}

[1] Ярошинська, О. О. (2016). Принципи проектування освітнього середовища професійної підготовки майбутніх учителів початкової школи. Наукові записки. Бердянський державний педагогічний університет. 312-318.

[2] Trubacheva, S., Onyschuk, L. (2019). Priority orientations of designing the educational environment of a gymnasium. Education: Modern Discourses. 2. 55-62. URL: http://emdnaes.org.ua/index.php/Educ_Mod_ discourse/article/view/50/53 https://doi.org/10.32405/2617-3107-2019-1-18

[3] Гонтаровська, Н. Б. (2005). Розвиток особистості в психолого-педагогчному контексті. Педагогіка і психологія. 1. 32-41.

[4] Гончар, О. В. (2012). Педагогічна взаємодія учасників навчального процесу в умовах дистанційної освіти. Збірник наукових праць Уманського державного педагогічного університету імені Павла Тичини. 1. 58-65.

[5] Доброханська, О. (2013). Освітнє середовище ЗН3 як фактор розвитку надпредметних компетентностей учнів. Рідна школа. 11(1007). 56-58.

[6] Трубачева, С. Е. (2019). Психолого-педагогічні особливості проектування освітнього середовища гімназії. Науковий вісник Ужгородського університету. Серія: «Педагогіка. Соціальна робота». 2 (45). 205-209.

[7] Трубачева, С., Замаскіна, П. (2020). Проєктування освітнього середовища гімназії з урахуванням особливостей дистанційного навчання. Науковий вісник Ужгородського університету. Серія: «Педагогіка. Соціальна робота». 2 (47). 195-199.

[8] Іванова, І. Б. (2007). Теоретико-методологічні засади навчання молоді в інтегрованому освітньому середовищі. Актуальні проблеми навчання та виховання людей з особливими потребами: збірник наукових праць. № 3(5). 188-197.

\section{References}

[1] Yaroshynska, O. O. (2016). Pryntsypy proektuvannia osvitnoho seredovyshcha profesiinoi pidhotovky maibutnikh uchyteliv pochatkovoi shkoly. Naukovi zapysky. Berdianskyi derzhavnyi pedahohichnyi universytet.312-318. (in Ukrainain).

[2] Trubacheva, S., Onyschuk, L. (2019). Priority orientations of designing the educational environment of a gymnasium. Education: Modern Discourses. 2. 55-62. URL: http://emdnaes.org.ua/index.php/Educ_Mod_ discourse/article/view/50/53 https://doi.org/10.32405/2617-3107-2019-1-18 (in Ukrainain).

[3] Hontarovska, N. B. (2005). Rozvytok osobystosti v psykholoho-pedahohchnomu konteksti. Pedahohika i psykholohiia. 1. 32-41. (in Ukrainain). 
[4] Honchar, O. V. (2012). Pedahohichna vzaiemodiia uchasnykiv navchalnoho protsesu v umovakh dystantsiinoi osvity. Zbirnyk naukovykh prats Umanskoho derzhavnoho pedahohichnoho universytetu imeni Pavla Tychyny. 1. 58-65. (in Ukrainain).

[5] Dobrokhanska, O. (2013). Osvitnie seredovyshche ZNZ yak faktor rozvytku nadpredmetnykh kompetentnostei uchniv. Ridna shkola. 11(1007). 56-58. (in Ukrainain).

[6] Trubacheva, S. E. (2019). Psykholoho-pedahohichni osoblyvosti proektuvannia osvitnoho seredovyshcha himnazii. Naukovyi visnyk Uzhhorodskoho universytetu. Seriia: «Pedahohika. Sotsialna robota». 2 (45). 205-209. (in Ukrainain).

[7] Trubacheva, S., Zamaskina, P. (2020). Proiektuvannia osvitnoho seredovyshcha himnazii z urakhuvanniam osoblyvostei dystantsiinoho navchannia. Naukovyi visnyk Uzhhorodskoho universytetu. Seriia: «Pedahohika. Sotsialna robota». 2 (47). 195-199. (in Ukrainain).

[8] Ivanova, I. B. (2007). Teoretyko-metodolohichni zasady navchannia molodi v intehrovanomu osvitnomu seredovyshchi. Aktualni problemy navchannia ta vykhovannia liudei z osoblyvymy potrebamy: zbirnyk naukovykh prats. № 3(5). 188-197. (in Ukrainain).

Svitlana Trubacheva, Candidate of Pedagogical Sciences, Senior Scientific Researcher, Head of the Department of Innovation and Strategies for the Development of Education of the Institute of Pedagogy of the NAES of Ukraine, Kyiv, Ukraine.

Oksana Mushka, Candidate of Pedagogical Sciences, Senior Scientific Researcher of the Department of Innovation and Strategies for the Development of Education of the Institute of Pedagogy of the NAES of Ukraine, Kyiv, Ukraine.

\section{TRADITIONS AND INNOVATIONS IN THE DESIGN OF THE EDUCATIONAL ENVIRONMENT OF THE MODERN GYMNASIUM}

The project of the educational environment provides its structural and system representation, which reflects the relationship of the main components, due to the purpose, goals and objectives of the educational process. The process of designing a model of the educational environment of the gymnasium includes the following aspects: conceptual, organizational and managerial, semantic, technological. The essence of both current traditional and innovative principles concerning the design of each of the highlighted components of the educational environment is revealed. The ways of their realization in the modern educational process of the gymnasium are analyzed.

Today, the basis of the educational environment of the gymnasium is its own educational program for grades 5-9, which, as we know, Ukrainian schools can develop on the basis of a typical educational program. This is especially important for demonstrating the specifics of the institution, the desire to take a certain position in the market of educational services, achieving a given level of competitiveness, improving the quality of educational services, expanding the range of specialties, developing a niche in the market of educational services. The systemic solution of these problems should be facilitated by the creation of the educational environment, which should be designed on the basis of current traditional and priority innovative didactic principles. Formation of subjectivity, formation and development of the social activity of participants of the project-pedagogical process, its quality and accessibility are one of the main criteria of its success and innovation.

The transformational processes taking place in education today make this problem relevant and in need of constant consideration of innovations. In particular, this statement is associated with the rapid development of the digitalization of education and the formation of the principles of digital didactics.

Keywords: educational environments; gymnasium; principles of designing the educational environment. 